\title{
Oral vanadate decreases muscle insulin resistance in obese fa/fa rats
}

\author{
S. M. Brichard, L. N. Ongemba and J. C. Henquin \\ Unité de Diabétologie et Nutrition, University of Louvain, Faculty of Medicine, Brussels, Belgium
}

\begin{abstract}
Summary. Oral vanadate has been reported as improving glucose homeostasis in genetically obese and hyperinsulinaemic fa/fa rats. It has also been shown that these beneficial effects could not be ascribed to the decrease in body weight induced by the treatment, or to changes in insulin counterregulatory hormones. The present study examined therefore whether the effects of vanadate could be attributed to a direct correction of the severe insulin resistance of these animals. fa/fa Rats chronically treated with vanadate were compared to both control rats fed ad libitum and pair-fed rats. The three groups were studied in the basal state and during euglycaemic hyperinsulinaemic clamps. Slightly lower plasma glucose levels were always maintained in vanadate-treated rats in conjunction with markedly lower plasma insulin levels either during basal or clamp studies. During the clamp, the glucose infusion rate required to maintain glycaemia at basal values was consistently higher in vanadate-treated rats than in the other two groups. Experiments using $\left[6-{ }^{3} \mathrm{H}\right] g l u c o s e ~ a s$
\end{abstract}

tracer showed that this was not due to a greater inhibition of hepatic glucose production by insulin, but corresponded to a larger increment in peripheral glucose disposal. The stimulation of overall glucose metabolic clearance induced by insulin was $129 \%$ and $41 \%$ higher in vanadate-treated than in control and pair-fed rats respectively. Similar experiments with 2 -deoxy-[1- $\left.{ }^{3} \mathrm{H}\right] \mathrm{glucose}$ as tracer showed that the larger increase in insulin-mediated glucose clearance occurred in various types of muscle. The action of insulin was particularly impressive on the cardiac muscle of vanadate-treated rats. In conclusion, the beneficial effects of vanadate on glucose homeostasis in obese hyperinsulinaemic fa/fa rats involve a sustained improvement of the impaired sensitivity to insulin in muscle.

Key words: Vanadate, insulin resistance, hyperinsulinaemic clamps, fa/fa rats, obesity, glucose metabolism.
Insulin resistance is a major characteristic of Type 2 (noninsulin-dependent) diabetes mellitus. However, the cellular mechanisms responsible for the alteration of insulin action are still unclear, and the therapeutic management of insulin-resistant states remains a challenge.

In vitro, various salts of the trace element vanadium exert insulin-like effects in skeletal muscle cells, adipocytes, hepatocytes and other cell types [1,2]. In vivo, oral vanadate lowers plasma glucose levels in insulin-deficient rats [3-6], and substantially improves glucose homeostasis in hyperinsulinaemic, insulin-resistant animals $[7,8]$. We previously reported that chronic treatment with vanadate partially corrected the hyperinsulinaemia and improved the tolerance to glucose loads in the genetically obese and mildly glucose-intolerant fa/fa rat [7]. This improvement could not be ascribed to the decrease in body weight gain or to a major change in insulin counterregulatory hormones $[7,9]$. Beneficial effects of vanadate may be due to a direct correction of tissue insulin resistance in these animals.
In the present study, we used the euglycaemic-hyperinsulinaemic clamp technique to investigate in vivo the effects of a chronic treatment with vanadate on the insulin action in fa/fa rats. The relative contributions of liver and peripheral tissues to the effects of vanadate were assessed during experiments with $\left.{ }^{3} \mathrm{H}\right]$ glucose infusion. Identification of the peripheral tissues involved in the effects of vanadate was attempted during experiments with 2-deoxy$\left[{ }^{3} \mathrm{H}\right]$ glucose injection.

\section{Materials and methods}

\section{Animals and protocol design}

Two series of 22 and 35 genetically obese (fa/fa) female Zucker rats (12-week-old) were purchased from the Centre de Sélection et d'Elevage d'Animaux de Laboratoire (CNRS, Orléans, France) and were housed in individual cages. All animals received a common rat chow in powdered form (A 04, Usine d'Alimentation Rationnelle, 
Epinay/Orge, France) and were maintained at a constant temperature $\left(21^{\circ} \mathrm{C}\right)$ with a fixed 12 -h light-dark cycle.

The animals were divided into three experimental groups. The control group ( $C ; n=19$ ) did not receive vanadate and was fed ad libitum. The vanadate-treated group $(\mathrm{V}, n=19)$ received increasing amounts of sodium orthovanadate $\left(\mathrm{Na}_{3} \mathrm{VO}_{4}\right.$, Janssen Chimica, Beerse, Belgium) in drinking solutions (up to $0.5 \mathrm{mg} / \mathrm{ml}$ ) and in food (up to $0.25 \mathrm{mg} / \mathrm{g}$ ) as previously described [7]. These latter concentrations were reached after 3 weeks of treatment and maintained constantly thereafter. By progressively increasing the amount of vanadate, the rats' aversion towards it was partially overcome. A third group of pair-fed rats $(\mathrm{P}-\mathrm{F} ; n=19)$ received a restricted amount of food to ensure a body weight gain similar to that of vanadate-treated rats. This amount, similar to that spontaneously ingested by vanadate-treated rats [7], was adjusted daily and administered in two rations (one-third at 10.00 hours and two-thirds at 18.00 hours). The three groups of rats were matched for initial body weight (g): $346 \pm 5$ (C), $348 \pm 5(\mathrm{P}-\mathrm{F}), 342 \pm 4(\mathrm{~V})$, and for fed plasma glucose levels (mean of two determinations, 1 and 2 days before treatment) $(\mathrm{mmol} / 1): 7.2 \pm 0.1(\mathrm{C}), 7.1 \pm 0.1(\mathrm{P}-\mathrm{F}), 7.1 \pm 0.1$ (V). The groups were also matched, as seen a posteriori, for fed plasma insulin levels (mU/1): $427 \pm 33(\mathrm{C}), 392 \pm 25(\mathrm{P}-\mathrm{F}), 366 \pm 14(\mathrm{~V})$.

The first series of rats $(n=22)$ was studied after 5 weeks of treatment: a tracer dose of $\left[6-{ }^{3} \mathrm{H}\right]$ glucose was infused to measure wholebody glucose production and glucose metabolic clearance under basal conditions and during euglycaemic hyperinsulinaemic clamps. The second series of rats $(n=35)$ was studied after 10 weeks of treatment: a tracer dose of 2 -deoxy $\left[1-{ }^{3} \mathrm{H}\right]$ glucose was infused to permit in vivo determination of basal and insulin-mediated glucose clearance index in individual tissues.

\section{Surgery}

Tests started at 09.00 hours in rats deprived of food for $15 \mathrm{~h}$ (thus, pair-fed rats did not receive their evening ration on the day before the experiment). The animals were anaesthetized with sodium pentobarbital (50 mg/kg i.p.) and ketamine (5 $\mathrm{mg} / \mathrm{kg}$ i.m.). Catheters were inserted in the right jugular vein for infusions and in the left carotid artery for blood sampling. A tracheotomy was performed to avoid respiratory difficulties during anaesthesia. Body temperature was monitored with a rectal thermometer and maintained between $36.5^{\circ} \mathrm{C}$ and $37.5^{\circ} \mathrm{C}$ with a heat lamp.

\section{Experiments with [6- $\left.{ }^{3} \mathrm{H}\right]$ glucose}

Basal. After completion of surgery, the rats received a priming dose $(3.75 \mu \mathrm{Ci})$ of D-[6- $\left.{ }^{3} \mathrm{H}\right]$ glucose (Amersham, Amersham, Bucks, UK) followed by a continuous infusion $(0.15 \mu \mathrm{Ci} / \mathrm{min})$ of the tracer to allow a steady-state specific activity of plasma glucose to be established [10]. Fifty min after the beginning of the tracer infusion, three successive blood samples $(-10,-5,0$ min before clamp) were taken for measurement of basal glycaemia, insulinaemia and $\left[{ }^{3} \mathrm{H}\right]$ glucose.

Euglycaemic hyperinsulinaemic clamp. Insulin (Actrapid HM; Novo Industri, Copenhagen, Denmark) was then infused at a dose of $24 \mathrm{mU} \cdot \mathrm{kg}^{-1} \cdot \mathrm{min}^{-1}$ for $210 \mathrm{~s}$, followed by infusion at a constant rate of $12 \mathrm{mU} \cdot \mathrm{kg}^{-1} \cdot \mathrm{min}^{-1}$ for the remainder of the experiment. Infusion of unlabelled glucose $(15 \mathrm{~g} / 100 \mathrm{ml}$ in water) was initiated $90 \mathrm{~s}$ after the beginning of insulin administration, and its rate of infusion was adjusted every 5 min to maintain glycaemia at basal values. After a 45-60 min equilibration period, a euglycaemic clamp was achieved in all rats. The steady glucose infusion rate (GIR) was then maintained during a further 30 -min period. During the last $10 \mathrm{~min}$ of the experiment, three additional blood samples were taken for determination of steady-state plasma glucose, plasma insulin and $\left[{ }^{3} \mathrm{H}\right]$ glucose specific activity.

Hepatic glucose production and whole-body glucose metabolic clearance [10-11]. When a steady-state glucose specific activity is reached in the basal state or during the clamp studies, the rate of glucose appearance is equal to the rate of glucose disappearance. These two parameters were calculated by dividing the $\left[6-{ }^{3} \mathrm{H}\right]$ glucose infusion rate $(\mathrm{dpm} / \mathrm{min})$ by the steady-state value of glucose specific activity $\left(\mathrm{dpm} \cdot \mathrm{mmol}^{-1}\right)$. In the basal state, HGP (hepatic glucose production) $=$ GUR (glucose utilization rate). During the clamp, HGP = GUR - GIR (exogenous glucose infusion rate). Data relative to peripheral glucose disposal were expressed as a glucose metabolic clearance $(\mathrm{GMC}=\mathrm{GUR} /$ blood glucose concentration) . GMC is an estimate of the overall efficiency of tissues to clear glucose from blood, that is almost independent from blood glucose concentration $[11,12]$, unless the differences in blood glucose levels are large [13], which was not the case in the present study.

\section{Experiments with 2-deoxy- $\left[^{3} \mathrm{H}\right]$ glucose}

Basal and clamp studies. A 30-min stabilization period always followed surgery. Then, either in the basal state, or when euglycaemia was reached in the clamp studies, a tracer dose of the non-metabolizable glucose analogue 2-deoxy-D-[1 $\left.{ }^{3} \mathrm{H}\right]$ glucose (Amersham) was administered as an i.v. bolus via the jugular catheter $(30 \mu \mathrm{Ci}$ in $300 \mu \mathrm{l}$ $0.9 \% \mathrm{NaCl}$ ). Arterial blood was then sampled at $1,3,5,10,20,30,45$ and $60 \mathrm{~min}$ in the basal state, or at 1,3,5,10,15,20,25,30 min during the clamp, for determination of plasma glucose and plasma tracer concentrations $[14,15]$. Plasma insulin was also measured in the last three samples. After completion of basal or clamp study, anaesthesia was deepened and several tissues were quickly removed in the following order: soleus, tibialis anterior, extensor digitorum longus, diaphragm, heart, jejunum, white periovarian adipose tissue (WAT) and interscapular brown adipose tissue. Pieces of about $100 \mathrm{mg}$ tissue (200 mg for WAT) were always taken in duplicate and immediately immersed in $500 \mu \mathrm{l}$ of $1 \mathrm{~mol} / \mathrm{l} \mathrm{NaOH}$, for determination of their 2-deoxy[1- $\left.{ }^{3} \mathrm{H}\right]$ glucose 6 phosphate content [14].

Glucose clearance index in individual tissues (glucose utilization index/blood glucose concentration) [16]. Glucose utilization in individual tissues was calculated by a method extensively discussed and validated elsewhere [14]. Briefly, the amount of 2-deoxy[1- $\left.{ }^{3} \mathrm{H}\right]$ glucose 6 phosphate contained per $\mathrm{mg}$ tissue $\left(\mathrm{dpm} \cdot \mathrm{mg}\right.$ tissue $\left.{ }^{-1}\right)$ was divided by the integral of the ratio of the concentrations of 2deoxy $\left[1-{ }^{3} \mathrm{H}\right] \mathrm{glucose} / \mathrm{glucose}\left(\mathrm{dpm} \cdot \mathrm{min}^{-1} \cdot \mathrm{mg}\right.$ glucose $\left.{ }^{-1}\right)$ measured in arterial plasma during the whole experiment. Since values were not corrected by the discrimination factor (lumped constant) for 2 deoxyglucose in glucose metabolic pathways $[15,17,18]$, the data must be considered as an index, rather than as absolute values.

\section{Analytical methods}

Plasma glucose was immediately measured by a glucose oxidase method (Glucose Analyzer, Beckman, Fullerton, Calif., USA). For measurements of the specific activity of $\left[6-{ }^{-3} \mathrm{H}\right]$ glucose or 2-deoxy[1$\left.{ }^{3} \mathrm{H}\right]$ glucose, $25 \mu \mathrm{l}$ plasma were deproteinized with $25 \mu \mathrm{l} \mathrm{ZnSO}_{4}$ $(300 \mathrm{mmol} / \mathrm{l})$ and $25 \mu \mathrm{l} \mathrm{Ba}(\mathrm{OH})_{2}(300 \mathrm{mmol} / \mathrm{l})$, and immediately centrifuged. An aliquot of the supernatant was used for the determination of glucose concentration using the glucose oxidase method. Another aliquot of the supernatant $(25 \mu \mathrm{l})$ was either directly counted in a liquid scintillation counter for determination of plasma 2-deoxy $\left[1-{ }^{3} \mathrm{H}\right] \mathrm{glucose}$ or first evaporated to dryness (to eliminate tritiated water) and redissolved in $100 \mu \mathrm{l}$ water for determination of plasma $\left[6-{ }^{3} \mathrm{H}\right]$ glucose. Plasma samples were then kept frozen at $-20^{\circ} \mathrm{C}$, until insulin measurement by a double antibody radioimmunoassay. Rat insulin (Novo Research Institute, Bagsvaerd, Denmark) was used as a standard for determination of basal insulinaemia and human insulin was used as a standard for determination of plasma insulin levels during the clamp. Vanadate did not interfere with the radioimmunoassay.

\section{Statistical analysis}

Results are given as the mean \pm SEM for the indicated number of rats. Comparisons between $\mathrm{C}, \mathrm{P}-\mathrm{F}$, and $\mathrm{V}$ rats were carried out by analysis of variance, followed by the Newman-Keuls test for 
Table 1. Effects of vanadate treatment on whole-body glucose metabolic clearance (GMC) and hepatic glucose production (HGP) in fa/fa rats under basal conditions and during euglycaemic hyperinsulinaemic clamp

\begin{tabular}{|c|c|c|c|c|c|c|}
\hline \multirow{2}{*}{\multicolumn{2}{|c|}{ Treatment $n$}} & \multicolumn{3}{|c|}{ Body $\quad$ GMC } & \multicolumn{2}{|c|}{$\begin{array}{l}\mathrm{HGP} \\
\left(\mathrm{mg} \cdot \mathrm{kg}^{-1} \cdot \mathrm{min}^{-1}\right)\end{array}$} \\
\hline & & & Basal & & Basal & \\
\hline & 8 & & & & & \\
\hline & 7 & $\pm 6^{\mathrm{a}}$ & $6.3 \pm$ & 11.1 & & \\
\hline Vanadate & 7 & $343 \pm 8^{a}$ & $6.5 \pm 0.5$ & $13.2 \pm 0.7^{a, b}$ & $7.3 \pm 0.6$ & $1.5 \pm 0.8$ \\
\hline
\end{tabular}

Values shown are mean \pm SEM.

Animals were studied after 5 weeks of treatment.

${ }^{\mathrm{a}} p<0.01$ vs control rats ${ }^{\mathrm{b}} p<0.05$ vs pair-fed rats

multiple comparisons [19]. Differences were considered statistically significant at $p<0.05$.

\section{Results}

Five-week experiments

At the end of the 5-week study, the body weight of control rats had increased from 340 to $394 \mathrm{~g}$. In contrast, vanadate-treated rats stopped gaining weight during the whole treatment period. The same body weight evolution was observed in pair-fed rats given restricted amounts of food similar to those spontaneously ingested by vanadatetreated rats (Table 1 ).

As previously reported [7], administration of vanadate to fa/fa rats affected both plasma glucose and insulin levels. Basal glucose levels of vanadate-treated rats were slightly lower than those of the other two groups and this difference persisted during the clamp (Fig.1). The effects of vanadate on plasma insulin levels were more pronounced. In the basal state, plasma insulin concentrations were decreased by about $40 \%$ ( $p<0.05$ vs C and P-F rats).
During exogenous insulin infusion, plasma insulin levels markedly increased in the three groups, but they remained lower in vanadate-treated rats than in the other two groups $(p<0.01)$ (Fig. 1). During the last $30 \mathrm{~min}$ of the clamp, the coefficients of variation of plasma glucose and insulin levels were less than 5 and $15 \%$ respectively.

Although plasma glucose and insulin levels were lower in vanadate-treated rats than in untreated animals during the clamp, the GIR required to maintain glycaemia at basal values was $62 \%$ higher than in control rats $(p<0.01)$ and $21 \%$ higher than in pair-fed rats $(p<0.05)$. GIR was less markedly increased by mere food restriction (34\% higher in $\mathrm{P}-\mathrm{F}$ than in $\mathrm{C}$ rats, $p<0.01$ ) (Fig. 1).

Overall peripheral glucose disposal was assessed by glucose metabolic clearance (GMC) since basal and clamp glucose concentrations were slightly lower in vanadate-treated rats and since glucose utilization depends on glycaemia [20]. Absolute values of whole-body GMC were similar in the three groups in the basal state, but were higher in vanadate-treated rats than in the other two groups during clamp (Table 1). The increment of GMC produced by insulin was $129 \%$ and $41 \%$ larger in treated animals than in control and pair-fed rats, respectively $(p<0.01)$ (Fig. 1).

Hepatic glucose production was similar in the three groups of rats in the basal state, and during inhibition by insulin infusion (Table 1). The percentage inhibition was not statistically different between control rats $(60 \%)$ and vanadate-treated rats (79\%).

\section{Ten-week experiments}

After 10 weeks of treatment, body weight, basal and clamp plasma glucose and insulin levels in the three groups of rats showed a pattern similar to that observed in first experiment (Table 2). As after 5 weeks of treatment,
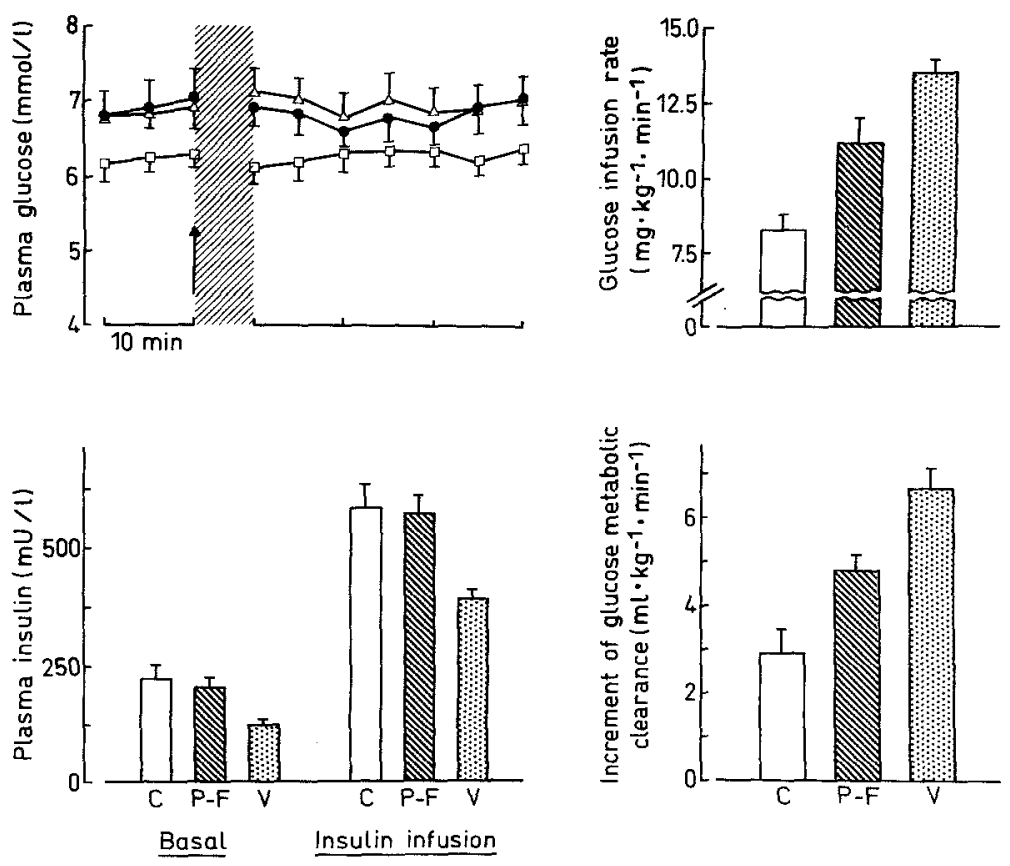

Fig.1. Left panels: Steady-state plasma glucose and insulin levels under basal conditions and during a euglycaemic hyperinsulinaemic clamp in control $(\mathrm{C}, \mathbf{0})$, pairfed $(P-F, \triangle)$ and vanadate-treated $(V, \square)$ fa/fa rats. The arrow shows the beginning of insulin infusion and the hatched area the equilibration period before clamp was reached. Right panels: Glucose infusion rate required to maintain euglycaemia during insulin infusion, and increment of glucose metabolic clearance over baseline during clamp. The experiments were performed after 5 weeks of treatment. Values are the mean \pm SEM for $8(\mathrm{C}), 7(\mathrm{P}-\mathrm{F})$ and $7(\mathrm{~V})$ rats 
Table 2. Body weight, plasma glucose and insulin levels in control, pair-fed and vanadate-treated fa/fa rats under basal conditions and during euglycaemic hyperinsulinaemic clamp

\begin{tabular}{|c|c|c|c|}
\hline & \multicolumn{3}{|c|}{ Treatment } \\
\hline & Control & Pair-fed & Vanadate \\
\hline Body weight (g) & $429 \pm 7$ & $342 \pm 5^{\mathrm{e}}$ & $342 \pm 8^{e}$ \\
\hline $\begin{array}{l}\text { Basal } \\
\text { Plasma glucose }(\mathrm{mmol} / \mathrm{l})^{\mathrm{a}} \\
\text { Plasma insulin }(\mathrm{mU} / \mathrm{l})^{c}\end{array}$ & $\begin{array}{c}6.3 \pm 0.2 \\
287 \pm 35\end{array}$ & $\begin{array}{c}6.8 \pm 0.2 \\
287 \pm 70\end{array}$ & $\begin{array}{c}6.0 \pm 0.3 \\
135 \pm 18^{\mathrm{f}, \mathrm{h}}\end{array}$ \\
\hline $\begin{array}{l}\text { Clamp } \\
\text { Plasma glucose }(\mathrm{mmol} / 1)^{\mathrm{b}} \\
\text { Plasma insulin }(\mathrm{mU} / \mathrm{l})^{\mathrm{c}} \\
\text { Glucose infusion rate } \\
\quad\left(\mathrm{mg} \cdot \mathrm{kg}^{-1} \cdot \mathrm{min}^{-1}\right)\end{array}$ & $\begin{array}{l}6.1 \pm 0.3 \\
743 \pm 73 \\
7.4 \pm 0.6\end{array}$ & $\begin{array}{c}6.5 \pm 0.6 \\
905 \pm 105 \\
6.1 \pm 0.2^{f}\end{array}$ & $\begin{array}{c}5.6 \pm 0.1 \\
534 \pm 28^{\mathrm{E}, \mathrm{g}} \\
10.9 \pm 0.4^{\mathrm{e}, \mathrm{f}}\end{array}$ \\
\hline
\end{tabular}

Values are mean \pm SEM for 11-12 rats in each group. One-half of the rats in each group were studied under basal conditions; the others during clamp. Measurements were taken after 10 weeks of treatment.

a Measured during the $60 \mathrm{~min}$ of basal study or ${ }^{\mathrm{b}}$ during the last 30 min of the clamp; "Mean of the three last samples during basal study or clamp; ${ }^{\mathrm{d}}$ Amount of glucose infused to maintain euglycaemia during clamp; ${ }^{\mathrm{e}} p<0.01,{ }^{\mathrm{f}} p<0.05$ vs control rats; ${ }^{\mathrm{g}} p<0.01$, ${ }^{\mathrm{h}} p<0.05$ vs pair-fed rats

GIR required to maintain basal glucose concentration during glucose infusion was higher in vanadate-treated rats than in the other two groups. In contrast, GIR was slightly decreased in pair-fed rats that had been submitted to food restriction for 10 weeks (Table 2).

As shown in Table 3, the indices of basal glucose clearance $(\mathrm{GC})$ were not different in any of the examined tissues (except diaphragm) in the three groups of rats. During the clamp, hyperinsulinaemia induced a rise in GC by all tissues in all groups. However, despite lower clamp insulin levels, absolute values of GC in vanadate-treated rats exceeded those in untreated animals in four out of five studied muscles and in the jejunum. Mere calorie restriction, in pair-fed rats, increased GC only in interscapular brown adipose tissue. The insulin-mediated increments of GC are illustrated in Figure 2. Insulin action was approximately $65-90 \%$ greater in all hind limb skeletal muscles of vanadate-treated rats ( $p<0.05-0.01)$, and was particularly impressive in the cardiac muscle of treated animals. The increase of $\mathrm{GC}$ in brown adipose tissue was similar in vanadate-treated and pair-fed rats and was two-fold larger than in control rats. When data were expressed as increment of $\mathrm{GC}$, there was no significant difference in the jejunum between the three groups (Fig. 2).

\section{Discussion}

Oral administration of vanadate has a marked hypoglycaemic action in adult rats made severely diabetic by injection of streptozotocin [3-6], and in rats made less severely diabetic and insulin-deficient by streptozotocin injection 5 days after birth [21] or by partial pancreatectomy [22]. In these three models, lowering of blood glucose was accompanied by a restoration of the effects of insulin on hepatic glucose production [6,21] and peripheral glucose disposal $[6,21,22]$.

Genetically obese and insulin-resistant fa/fa rats are only mildly glucose-intolerant [23-26]. As reported in our previous study [7], vanadate marginally decreased basal glucose levels, but lowered basal insulin levels by $40-50 \%$ in these rats. This situation is suggestive of an alleviation of the insulin resistance, that could be conclusively established by the euglycaemic-hyperinsulinaemic clamp technique. Although equivalent doses of insulin were infused, lower plasma levels of the hormone were measured during the clamp in vanadate-treated than in control rats. This can partly be explained by the lower basal insulin concentrations in treated rats, but an increased clearance rate of insulin in these animals cannot be ruled out.

Under our experimental conditions, the glucose infusion rate during the euglycaemic clamp can be regarded as an estimate of overall whole-body insulin action. It was higher in vanadate-treated rats than in the other two groups, regardless of the length of treatment. In pair-fed rats, on the other hand, this rate of infusion was slightly higher than in control animals after 5 weeks and slightly lower after 10 weeks. This clearly indicates that the effects

Table 3. Effects of vanadate treatment on glucose clearance by various tissues under basal conditions or during euglycaemic hyperinsulinaemic clamp in fa/fa rats

\begin{tabular}{|c|c|c|c|c|c|c|}
\hline & \multicolumn{3}{|l|}{ Basal } & \multicolumn{3}{|l|}{ Clamp } \\
\hline & Control & Pair-fed & Vanadate & Control & Pair-fed & Vanadate \\
\hline & \multicolumn{3}{|c|}{$\mathrm{nl} \cdot \mathrm{mg}$ tissue ${ }^{-1} \cdot \min ^{-1}$} & \multicolumn{3}{|c|}{$\mathrm{nl} \cdot \mathrm{mg}$ tissue ${ }^{-1} \cdot \min ^{-1}$} \\
\hline $\begin{array}{l}\text { Adipose } \\
\text { White } \\
\text { Brown }\end{array}$ & $\begin{array}{l}1.0 \pm 0.1 \\
2.0 \pm 0.3\end{array}$ & $\begin{array}{l}1.0 \pm 0.2 \\
3.4 \pm 1.1\end{array}$ & $\begin{array}{l}0.6 \pm 0.1 \\
0.9 \pm 0.1\end{array}$ & $\begin{array}{r}1.8 \pm 0.6 \\
12.3 \pm 2.6\end{array}$ & $\begin{array}{c}1.4 \pm 0.2 \\
28.1 \pm 3.4^{\mathrm{b}}\end{array}$ & $\begin{array}{r}1.4 \pm 0.1 \\
21.5 \pm 3.4\end{array}$ \\
\hline Jejunum & $9.9 \pm 0.7$ & $9.4 \pm 0.7$ & $11.5 \pm 1.8$ & $15.6 \pm 0.6$ & $13.5 \pm 0.8$ & $18.8 \pm 1.5^{c}$ \\
\hline
\end{tabular}

Values are mean \pm SEM for 5-6 control, pair-fed or vanadate-treated rats. Animals were studied after 10 weeks of treatment.

TA, tibialis anterior; EDL, extensor digitorum longus; DIA, diaphragm.

${ }^{\mathrm{a}} p<0.01,{ }^{\mathrm{b}} p<0.05$ vs control rats; ${ }^{\mathrm{c}} p<0.01,{ }^{\mathrm{d}} p<0.05$ vs pair-fed rats 

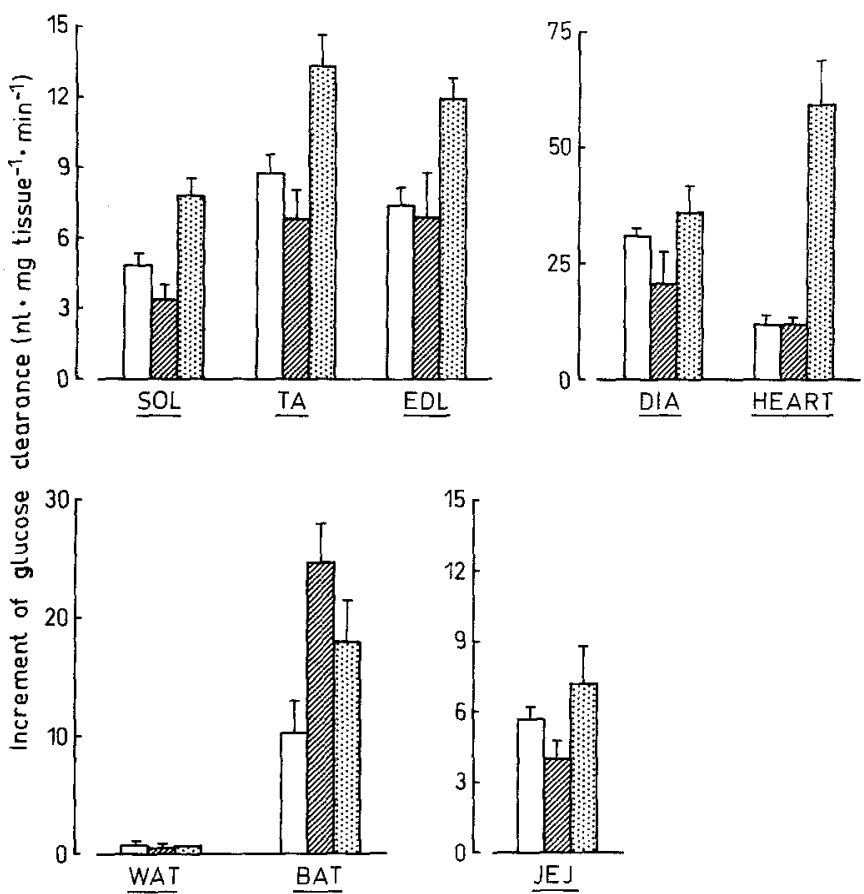

Fig.2. Insulin-stimulated increment of glucose clearance by various tissues in fa/fa rats. Values are the mean \pm SEM for $5-6$ control $(\square)$, pair-fed (ש) or vanadate-treated (丽) rats. These animals were submitted to insulin-clamp studies after 10 weeks of treatment. Basal samples were obtained from six other rats in each group (see Materials and methods). SOL, soleus; TA, tibialis anterior; EDL; extensor digitorum longus; DIA, diaphragm; WAT, white adipose tissue; BAT, brown adipose tissue; JEJ, jejunum

of vanadate are not primarily due to the lower body weight gain of the rats, and further suggests that mere food restriction only transiently improved insulin sensitivity in fa/fa rats. These observations are consistent with our previous report that the plasma insulin/glucose ratio only initially decreases in these P-F fa/fa rats [7]. They are also in agreement with a study showing that a paradoxical worsening of insulin resistance can develop in fa/fa rats submitted to mild food restriction for several weeks [27]. This interesting issue may deserve further investigation.

Experiments with $\left[{ }^{3} \mathrm{H}\right]$-glucose as tracer evidenced a similar rate of glucose turnover under basal conditions in vanadate-treated, pair-fed and control rats, whereas the glucose metabolic clearance rate was higher in vanadatetreated rats than in the other two groups during stimulation by insulin. This was observed despite lower basal and clamp insulin levels and thus reflects an improvement of insulin action in these animals. The data also suggest that this improvement involves peripheral tissues rather than the liver since the suppression of hepatic glucose production by insulin was not significantly increased by vanadate treatment. However, the possibility that effects of vanadate on the liver would be disclosed after longer periods of treatment or if smaller amounts of insulin were infused during the clamp cannot be excluded.

Experiments using 2-deoxyglucose as tracer were therefore performed to identify the possible target tissues of vanadate. Previous in vivo studies combining the euglycaemic hyperinsulinaemic clamp with injection of 2-de- oxyglucose have clearly documented the marked insulin resistance of skeletal muscles and adipose tissues in adult obese fa/fa rats [28]. Vanadate treatment mainly increased insulin-stimulated glucose clearance by muscles, did not modify insulin action in white adipose tissue and exerted only a non-specific effect on brown adipose tissue, since the latter increase in insulin effectiveness also occurred in pair-fed rats. Thus, muscle, the major site of insulin-mediated glucose disposal [17], appears to be the principal target tissue of vanadate action in $\mathrm{fa} / \mathrm{fa}$ rats in vivo. We previously observed that chronic administration of vanadate to ob/ob mice, another model of insulin resistance, increased in vitro glucose oxidation in muscle tissue but not in white adipose tissue [8].

The effects of vanadate are reminiscent of those of metformin, a biguanide that lowers both plasma glucose and insulin levels in non-insulin-dependent diabetes. However, the hypoglycaemic effect of metformin in the fa/fa rat is mainly due to an increased glucose utilization by the digestive tract rather than by muscles, which remain markedly insulin-resistant [15]. The mechanisms of action of vanadate and metformin are thus different.

The most impressive improvement of insulin action produced by vanadate treatment was observed in cardiac muscle. This may be unexpected since glucose is not the major myocardial fuel. It is, however, known that glucose uptake by the heart is markedly reduced in uncontrolled diabetes [29]. This metabolic effect of vanadate in the heart may perhaps explain how the element prevents the decline in cardiac performance in diabetic rats $[3,30,31]$. It could be useful to investigate further the beneficial effects of vanadate on diabetic cardiomyopathy, in particular when the insulin resistance limits the effectiveness of insulin therapy.

The insulin-like effects of vanadium salts in vitro, are usually observed at concentrations several-fold higher than the plasma levels of vanadium in animals given oral vanadate $[1,2]$. In streptozotocin-diabetic rats treated with vanadyl, tissue vanadium concentrations approached those effective in vitro only in the liver, kidney and bone [32]. This observation prompted the suggestion that muscles might not be a primary target for the action of vanadium in vivo. The present study clearly shows this not to be the case. Recent in vitro studies have also suggested that vanadium may increase the effects of insulin on isolated cells at lower concentrations than those necessary to produce acute insulin-like effects [32].

In conclusion, the beneficial effects of oral vanadate on glucose homeostasis in obese hyperinsulinaemic fa/fa rats can be ascribed to a sustained improvement of muscle sensitivity to insulin. This raises obvious therapeutic possibilities in states of insulin resistance. However, complete and cautious evaluation of the potential side-effects of the element is required before administration of vanadate to human patients is attempted.

Acknowledgements. This work was supported by Grant $1.5 .118 .90 \mathrm{~F}$ from the Fonds National de la Recherche Scientifique, Brussels, Belgium and by a Grant-in-aid from Bayer-Belgium. S.M. B. is Chargé de Recherches, and J. C.H. is Directeur de Recherches of the FNRS, Brussels, Belgium. We are grateful to Mr. M.Gérard and Ms. 
A.M.Pottier for skilful assistance, and to Ms. M. Nenquin for editorial help.

\section{References}

1. Posner BI, Shaver A, Fantus IG (1990) Insulin mimetic agents: vanadium and peroxovanadium compounds. In: Bailey CJ, Flatt PR (eds) New antidiabetic drugs. Smith-Gordon, London, pp 107-118

2. Shechter Y (1990) Insulin mimetic effects of vanadate. Possible implications for future treatment of diabetes. Diabetes 39: 1-5

3. Heyliger CE, Tahiliani AG, McNeill JH (1985) Effect of vanadate on elevated blood glucose and depressed cardiac performance of diabetic rats. Science 227: 1474-1477

4. Meyerovitch J, Farfel Z, Sack J, Shechter Y (1987) Oral administration of vanadate normalizes blood glucose levels in streptozotocin-treated rats. J Biol Chem 262: 6658-6662

5. Brichard SM, Okitolonda W, Henquin JC (1988) Long term improvement of glucose homeostasis by vanadate treatment in diabetic rats. Endocrinology 123: 2048-2053

6. Blondel O, Bailbe D, Portha B (1989) In vivo insulin resistance in streptozotocin-diabetic rats - evidence for reversal following oral vanadate treatment. Diabetologia 32: $185-190$

7. Brichard SM, Pottier AM, Henquin JC (1989) Long term improvement of glucose homeostasis by vanadate in obese hyperinsulinemic fa/fa rats. Endocrinology 125: 2510-2516

8. Brichard SM, Bailey CJ, Henquin JC (1990) Marked improvement of glucose homeostasis in diabetic ob/ob mice given oral vanadate. Diabetes 39:1326-1332

9. Brichard SM, Ongemba LN, Kolanowski J, Henquin JC (1991) The influence of vanadate on insulin counter-regulatory hormones in obese fa/fa rats. J Endocrinol 131: 185-191

10. Terrettaz J, Jeanrenaud B (1983) In vivo hepatic and peripheral insulin resistance in genetically obese (fa/fa) rats. Endocrinology 112: $1346-1351$

11. Leturque A, Burnol AF, Ferre P, Girard J (1984) Pregnancy-induced insulin resistance in the rat: assessment by glucose clamp technique. Am J Physiol246: E25-E31

12. Cherrington AD, Williams PE, Harris MS (1978) Relationship between the plasma glucose level and glucose uptake in the conscious dog. Metab Clin Exp 27: 787-791

13. Kergoat M, Portha B (1985) In vivo hepatic and peripheral insulin sensitivity in rats with non-insulin-dependent diabetes induced by streptozotocin: assessment with the insulin-glucose clamp technique. Diabetes 34: 1120-1126

14. Ferre P, Leturque A, Burnol AF, Penicaud L, Girard J (1985) A method to quantify glucose utilization in vivo in skeletal muscle and white adipose tissue of the anaesthetized rat. Biochem J 228: $103-110$

15. Penicaud L, Hitier Y, Ferre P, Girard J (1989) Hypoglycaemiceffect of metformin in genetically obese (fa/fa) rats results from an increased utilization of blood glucose by intestine. Biochem $J$ 262: $881-885$

16. Leturque A, Ferre P, Burnol AF, Kande J, Maulard P, Girard J (1986) Glucose utilization rates and insulin sensitivity in vivo in tissues of virgin and pregnant rats. Diabetes 35:172-177

17. Kraegen EW, James DE, Jenkins AB, Chisholm DJ (1985) Doseresponse curves for in vivo insulin sensitivity in individual tissues in rats. Am J Physiol 248: E353-E362
18. Smith SA, Young P, Cawthorne MA (1986) Quantification in vivo of the effects of insulin on glucose utilization in individual tissues of warm and cold acclimated rats. Biochem J 237: 789-795

19. Sokal RR, Rohlf FJ (1969) Biometry. The principles and practice of statistics in biological research. Freeman, San Francisco, pp $1-776$

20. Verdonck CA, Rizza RA, Gerich JE (1981) Effects of plasma glucose concentration on glucose utilization and glucose clearance in normal man. Diabetes 30: 535-537

21. Blondel O, Simon J, Chevalier B, Portha B (1990) Impaired insulin action but normal insulin receptor activity in diabetic rat liver: effect of vanadate. Am J Physiol 258: E459-E467

22. Rossetti L, Laughlin MR (1989) Correction of chronic hyperglycemia with vanadate, but not with phlorizin, normalizes in vivo glycogen repletion and in vitro glycogen synthase activity in diabetic skeletal muscle. J Clin Invest 84: 892-899

23. Zucker LM, Antoniades HN (1972) Insulin and obesity in the Zucker genetically obese rat "fatty". Endocrinology 90: 13201330

24. Bray GA (1977) The Zucker-fatty rat: a review. Fed Proc 36: 148 153

25. Ionescu E, Sauter JF, Jeanrenaud B (1985) Abnormal glucose tolerance in genetically obese (fa/fa) rats. Am J Physiol 248: E500-E506

26. Rohner-Jeanrenaud F, Proietto J, Ionescu E, Jeanrenaud B (1986) Mechanism of abnormal glucose tolerance of genetically obese fa/fa rats. Diabetes 35: 1350-1355

27. Lemonnier D, de Gasquet P, Mackay S et al. (1989) Different levels of food restriction have opposite effects on adipocyte cellularity and lipoprotein-lipase activity in obese rats. Diabète Metab 15: 394-402

28. Penicaud L, Ferre P, Terretaz J et al. (1987) Development of obesity in Zucker rats. Early insulin resistance in muscles but normal sensitivity in white adipose tissue. Diabetes $36: 626-631$

29. Opie L (1984) The heart. Grune and Stratton, Orlando pp 111135

30. Paulson DJ, Kopp SJ, Tow JP, Peace DG (1987) Effects of vanadate on in vivo myocardial reactivity to norepinephrine in diabetic rats. J Pharmacol Exp Ther 240: 529-534

31. Ramanadham S, Mongold JJ, Brownsey RW, Cros GH, McNeill JH (1989) Oral vanadyl sulfate in treatment of diabetes mellitus in rats. Am J Physiol 257: H904-H911

32. Mongold JJ, Cros GH, Vian L et al. (1990) Toxicological aspects of vanadyl sulphate on diabetic rats: effects on vanadium levels and pancreatic B-cell morphology. Pharmacol Toxicol 67: 192198

33. Fantus IG, Ahmad F, Deragon G (1990) Vanadate augments insulin binding and prolongs insulin action in rat adipocytes. Endocrinology 127: 2716-2725

Received: 11 November 1991

and in revised form: 31 January 1992

Dr. J.C.Henquin

Unité de Diabétologie et Nutrition

UCL 54.74

Avenue Hippocrate 54

B-1200 Brussels

Belgium 